\title{
Evaluation and Application of Liquid Chromatographic Columns Coated with "Intelligent" Ligands. (III) Immobilized Enzyme Phospholipid Column
}

\author{
Hiroshi KAMIMORI ${ }^{\dagger}$ and Masaharu KONISHI \\ Shionogi Research Laboratories, Shionogi \& Co., Ltd., Fukushima, Osaka 553-0002, Japan
}

\begin{abstract}
Immobilized enzyme columns have been developed for use as high-performance liquid chromatographic enzyme reactors. Enzyme reactors were prepared by immobilizing trypsin or cytochrome- $c$ on phospholipid columns. Dynamic coating was employed to prepare the reactors by recycling a buffer solution containing trypsin or cytochrome-c through a phospholipid-coated column, on which the enzymes were immobilized by hydrophobic binding. The immobilized trypsin column displayed hydrolytic activity which catalyzed the hydrolysis of L-amino acid esters to amino acid. The immobilized cytochrome- $c$ column exhibited oxidation activity which catalyzed $N$-demethylation of $N, N$-dimethylaniline, codeine, and dihydrocodeine in the presence of hydrogen peroxide as an oxygenating agent. The enzyme reaction proceeded rapidly in the column; both product and substrate could be separated and detected simultaneously. The immobilized enzyme columns could be readily regenerated using the original phospholipid column by repeating the dynamic coating. These immobilized enzyme columns could be utilized as enzyme reactors in the high-performance liquid chromatographic mode. Complete hydrolysis of amino acid ester was observed with the trypsin column. Demethylation of codeine and of dihydrocodeine were observed with the cytchrome- $c$ column.
\end{abstract}

(Received April 18, 2001; Accepted June 28, 2001)

\section{Introduction}

Immobilized enzyme reactors (IMER) have been developed for use as high-performance liquid chromatographic (HPLC) columns and have been used as pre- or postcolumns in HPLC systems for on-line analysis of biological substances. ${ }^{1-5}$ IMER have also been used to study the enzymatic enantioselective recognition of racemic compounds. ${ }^{6,7}$ While the IMER offer the practical advantage of the immobilized enzyme tolerating repetitive use, there are intrinsic problems resulting from the limited conformational mobility due to the covalent immobilization of enzymes on the supports. ${ }^{8}$ Recently, Wainer et al. immobilized an enzyme on an immobilized artificial membrane (IAM) ${ }^{9}$ to utilize the biomimetic character of the IMER column in enzyme-catalyzed reactions. They prepared the IMER by recycling a solution containing enzyme through the IAM column. The conformational mobility of the enzyme was expected to be closer to the natural enzyme and the IMER column expressed its enzymatic activities. They concluded that the immobilized enzyme IAM columns are useful for finding enzyme/substrate and enzyme/inhibitor interactions. . $^{810-12}$

In this study, we prepared immobilized enzyme columns as enzyme reactors using the phospholipid column. We have previously prepared ODS coated with phospholipid as a model of lipid membranes for HPLC column (phospholipid column) and estimated the separation characteristics of the columns. ${ }^{13} \mathrm{We}$ are now focusing on the suitability of the phospholipid column as a support for enzyme immobilization. The immobilized

$\doteqdot$ To whom correspondence should be addressed.

E-mail: hiroshi.kamimori@shionogi.co.jp enzyme prepared in this manner was expected to be stabilized by hydrophobic binding to the phospholipid in the column.

This paper describes the method for preparing columns with two immobilized enzymes, trypsin and cytochrome- $c$, and also describes their characteristics as enzyme reactors and their usage for drug development.

\section{Experimental}

\section{Materials}

Trypsin was obtained from Funakoshi (from porcine pancreas, Tokyo, Japan) and cytochrome- $c$ (Cty-c) was purchased from Sigma Chemical Co. (from horse heart, Type VI). L-Histidine (L-His), L-histidine methyl ester (L-His-OMe) dihydrochloride, $\alpha$ - $N$-benzoyl-L-arginine (BA), $\alpha$ - $N$-benzoyl-L-arginine ethyl ester (BAEE) hydrochloride, $N, N$-dimethylaniline (DMA), $N$ methylanilne (MA), and aniline (AN) were purchased from Nacalai Tesque (Kyoto, Japan). Dihydrocodeine (DHC) phosphate and codeine $(\mathrm{C})$ phosphate were obtained from Shionogi \& Co., Ltd (Osaka, Japan). Dihydronorcodeine (DHNC) hydrochloride and Norcodeine (NC) hydrochloride were synthesized in our laboratories. Water was purified before use with ultrapure-water generating equipment (Bansteads, Boston, MA). Acetonitrile and trifluoroacetic acid were of HPLC grade and all other chemicals were of reagent grade. The HPLC columns used were an L-column ODS $(150 \times 4.6 \mathrm{~mm}$ i.d., $5 \mu \mathrm{m}$, Chemical Evaluation and Research Institute, Tokyo, Japan $)$, a Cosmosil $5 \mathrm{C} 18(30 \times 4.6 \mathrm{~mm}$ i.d., $5 \mu \mathrm{m}$, Nacalai Tesque, Kyoto, Japan), a Cosmosil 5C8 $(30 \times 4.6 \mathrm{~mm}$ i.d., Nacalai Tesque, Kyoto, Japan), and a Develosil TMS-5 (10 $\times$ $4.6 \mathrm{~mm}$ i.d., $5 \mu \mathrm{m}$, Nomura Chemicals, Aichi, Japan). 


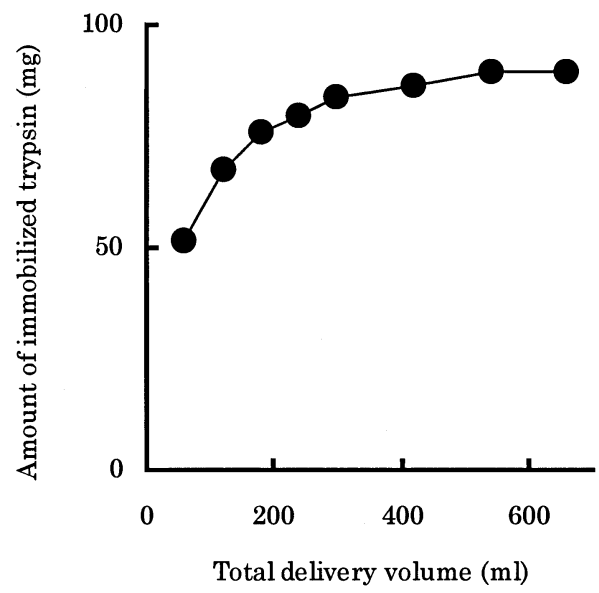

Fig. 1 Relationship between the total delivery volumes of enzyme solution and the amount of trypsin immobilized on the phospholipid column. Enzyme solution: $50 \mathrm{ml}$ of $0.1 \mathrm{~mol} / 1$ sodium phosphate buffer ( $\mathrm{pH}$ 7) containing $100 \mathrm{mg}$ of trypsin; flow rate: $1 \mathrm{~mL} / \mathrm{min}$; column: phospholipid column $(150 \times 4.6 \mathrm{~mm}$ i.d. $)$.

\section{HPLC conditions}

A Waters 600E Multisolvent Delivery System (Milford, MA) was used to deliver the mobile phase. Sample solutions were injected with a Shimadzu SIL-9A automatic injector (Kyoto, Japan), and the detector was a Shimadzu SPD-10AV spectrophotometer. The chromatographic data were analyzed using a Shimadzu C-R4AX data processor. The column temperature was controlled with heating equipment (Model 370; Chemco, Osaka, Japan). The photodiode-array system was performed with a Hewlett-Packard 1050 series (San Diego, CA).

\section{Preparation of immobilized enzyme columns}

The phospholipid columns used to prepare the immobilized enzyme columns were an L-column ODS $(150 \times 4.6 \mathrm{~mm}$ i.d. $)$ coated with L-dipalmitoylphosphatidylcholine (DPPC) and a Cosmosil 5C18 $(30 \times 4.6 \mathrm{~mm}$ i.d. $)$ coated with DPPC. The phospholipid columns were prepared by a dynamic coating technique developed in our laboratories. ${ }^{13}$ The procedure was done under an ambient temperature of $25 \pm 1{ }^{\circ} \mathrm{C}$. An immobilized trypsin column was prepared as follows: A solution of $100 \mathrm{mg}$ of trypsin dissolved in $50 \mathrm{ml}$ of a 100 mmol/l sodium phosphate buffer $(\mathrm{pH} 7)$ was pumped via recycling at a flow rate of $1 \mathrm{ml} / \mathrm{min}$ through the phospholipid column $(150 \times 4.6 \mathrm{~mm}$ i.d. $)$ in a closed loop for up to $600 \mathrm{ml}$ of total delivery. Similarly, an immobilized Cyt- $c$ column was prepared by recycling a solution of $20 \mathrm{mg}$ of Cyt- $c$ dissolved in $50 \mathrm{ml}$ of a $10 \mathrm{mmol} / \mathrm{L}$ sodium phosphate buffer $(\mathrm{pH} 7)$ at a flow rate of $1 \mathrm{ml} / \mathrm{min}$ through the phospholipid-column $(30 \times 4.6 \mathrm{~mm}$ i.d.) for up to $120 \mathrm{ml}$ of total delivery. The immobilized enzyme columns were washed with sodium phosphate buffer $(\mathrm{pH} 7)$ at $1 \mathrm{ml} / \mathrm{min}$ for $30 \mathrm{~min}$. The immobilized enzyme columns were stored in a refrigerator at $4^{\circ} \mathrm{C}$ until use.

The amount of immobilized enzyme on the phospholipid column was calculated from differences in the concentrations of the solutions containing enzyme before and after preparing the immobilized enzyme column. The concentrations of the solutions were determined with gradient elution by HPLC. The mobile phases used were $0.1 \%$ trifluoroacetic acid solution/acetonitrile $(65: 35, \mathrm{v} / \mathrm{v})$ and $0.1 \%$ trifluoroacetic acid solution/acetonitrile $(50: 50, \mathrm{v} / \mathrm{v})$ at a total flow rate of $1 \mathrm{ml} / \mathrm{min}$ for determination of tyrpsin. Similarly the mobile phases used (a)

(b)
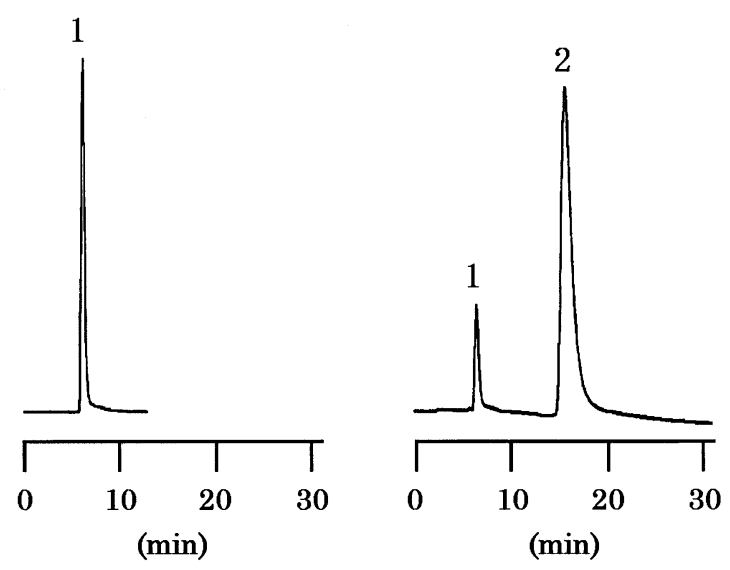

Fig. 2 Chromatograms of hydrolysis of L-histidine methyl ester on immobilized trypsin column. (a) L-histidine $(50 \mathrm{nmol})$ and (b) Lhistidine methyl ester $(50 \mathrm{nmol})$. Mobile phase: $10 \mathrm{mmol} / \mathrm{l}$ sodium phosphate buffer ( $\mathrm{pH} 6.8$ ); flow rate: $0.25 \mathrm{ml} / \mathrm{min}$; detection: $230 \mathrm{~nm}$; column: immobilized tyrpsin column $(150 \times 4.6 \mathrm{~mm}$ i.d. $)$; column temperature: $25^{\circ} \mathrm{C}$. Peaks: 1, L-histidine; 2 , L-histidine methyl ester.

were $0.05 \%$ trifluoroacetic acid solution/acetonitrile $(80: 20, \mathrm{v} / \mathrm{v})$ and $0.05 \%$ trifluoroacetic acid solution/acetonitrile $(50: 50, \mathrm{v} / \mathrm{v})$ at a total flow rate of $1 \mathrm{ml} / \mathrm{min}$ for determination of Cty-c. The analytical column used was Cosmosil $5 \mathrm{C} 8(30 \times 4.6 \mathrm{~mm}$ i.d. $)$ and the detector was operated at the wavelength of $220 \mathrm{~nm}$. A $10 \mu \mathrm{l}$ aliquot of the solution containing enzyme was injected onto the HPLC.

\section{Estimated activities of the immobilized enzyme columns}

The hydrolytic activity of the immobilized trypsin column was estimated by measuring L-His and BA when L-His-OMe and BAEE were injected onto the column delivering $10 \mathrm{mmol} / \mathrm{l}$ sodium phosphate buffer ( $\mathrm{pH}$ 6.8) as the mobile phase. The $N$ demethylase activity of the immobilized Cyt-c column was estimated by measuring MA, AN, DHNC and NC when hydrogen peroxide solution was injected onto the column after the injection of DMA, DHC and C delivered via $10 \mathrm{mmol} / \mathrm{l}$ sodium phosphate buffer ( $\mathrm{pH}$ 7.0) as the mobile phase. The product yields were calculated from the peak area of the formed products and compared with that of the standard solution of product injected onto the column under the same analysis conditions.

\section{Results and Discussion}

\section{Immobilization of enzymes on phospholipid column}

Figure 1 shows the relationship between the total volumes of the enzyme solution delivered through the phospholipid column and the amount of trypsin immobilized on the column. The trypsin amount increased with the increase in the volume of the enzyme solution delivered and reached a plateau when the total volume was $600 \mathrm{ml}$. As a result, approximately $90 \mathrm{mg}$ of trypsin was immobilized on the phospholipid column $(150 \times 4.6$ $\mathrm{mm}$ i.d.). Similarly, the amounts of Cty- $c$ immobilized on the phospholipid column $(30 \times 4.6 \mathrm{~mm}$ i.d. $)$ were estimated to be approximately $8 \mathrm{mg}$ by employing the same immobilization procedure. 
Table 1 Relationship between flow rate of mobile phase and yields of L-histidine from L-histidine methyl ester on immobilized trypsin column

\begin{tabular}{ccccc}
\hline $\begin{array}{c}\text { Flow rate/ } \\
\mathrm{ml} \mathrm{min}^{-1}\end{array}$ & $\begin{array}{c}\text { Retention time } \\
\text { of L-His-OMe } \\
\text { min }\end{array}$ & $\begin{array}{c}\text { Retention time } \\
\text { of L-His/ } \\
\text { min }\end{array}$ & $\begin{array}{c}\text { Product of } \\
\text { L-His/ } \\
\text { nmol }\end{array}$ & $\begin{array}{c}\text { Yield of } \\
\text { L-His, \% }\end{array}$ \\
\hline 0.10 & 39.5 & 16.2 & 15.3 & 31 \\
0.25 & 15.6 & 6.4 & 7.3 & 15 \\
0.30 & 13.0 & 5.4 & 6.8 & 14 \\
\hline
\end{tabular}

Injection amount of substrate was $50 \mathrm{nmol}$ of L-His-OMe.

a. L-Hisitidine methyl ester.

b. L-Histidine.

\section{Evaluation of immobilized trypsin column}

Figure 2 shows the chromatograms when $50 \mathrm{nmol}$ each of substrate L-His-OMe or standard L-His was injected onto the immobilized trypsin column with the mobile phase of sodium phosphate buffer $(\mathrm{pH}$ 6.8). The retention time of the peak eluting earlier (Fig. 2b) was identical with the standard L-His (Fig. 2a), indicating that L-His was formed by hydrolysis of the L-His-OMe moving through the column. Both the product and the substrate were completely separated and detected. Table 1 shows the relationship between the flow rate of mobile phase delivered through the column and the yields of L-His from LHis-OMe, when $50 \mathrm{nmol}$ of L-His-OMe was injected. The flow rate of the mobile phase was dependent on the substrate hydrolysis as the yields of L-His from L-His-OMe were $14 \%$ at $0.3 \mathrm{ml} / \mathrm{min}$ and $31 \%$ at $0.1 \mathrm{ml} / \mathrm{min}$, respectively. Extending the reaction time in the column by decreasing the flow rate might enhance the reaction yield. The hydrolysis reaction of L-HisOMe was not affected by the column temperature.

Figure 3 shows the chromatograms when $1000 \mathrm{nmol}$ of BAEE was injected onto the immobilized trypsin column with the mobile phase of sodium phosphate buffer ( $\mathrm{pH}$ 6.8). The retention time of the eluted peak (Fig. 3b) was identical to that of standard BA (Fig. 3a) and no unchanged BAEE was observed under this condition. If some unreacted substrate were remaining in the immobilized trypsin column, both the product and the substrate should have been separated and detected through the ODS column connected with the immobilized trypsin column. The injected BAEE was confirmed to be quantitatively hydrolyzed to BA while moving through the column, because a corresponding amount of BA was found to be eluted when the peak area of the product was compared with that of the standard BA. The peak of BA formed by hydrolysis of BAEE was somewhat broad compared to that of the standard BA under this condition. The broadening peak of the substrate injected onto the column would result in the broad peak of the product under this condition.

The hydrolysis products were identified by HPLC with photodiode-array detection. The peak fractions containing the hydrolysis products were collected and the fraction solutions were subjected to HPLC. The uv spectra of L-His and BA obtained from the fractions were identical with those of their standards.

On the other hand, the hydrolysis activity of the immobilized trypsin ODS column was less than $70 \%$ of the immobilized trypsin phospholipid column for hydrolysis of L-His-OME. The hydrolysis activity of the immobilized trypsin ODS column decreased as the volumes of buffer solution delivered increased, and the column finally became inactive. The activity of the immobilized trypsin phospholipid column remained unchanged (a)

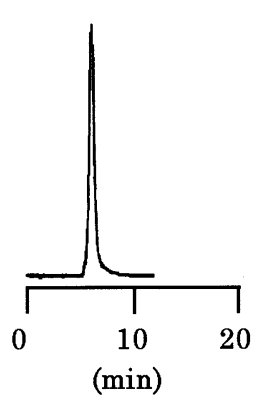

(b)

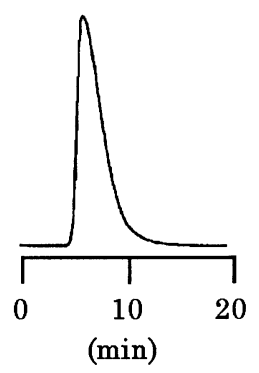

Fig. 3 Chromatograms of hydrolysis of $\alpha$ - $N$-benzoyl-L-arginine ethyl ester on immobilized trypsin column. (a) $\alpha$ - $N$-benzoyl-Larginine $(10 \mathrm{nmol})$ and (b) $\alpha$ - $N$-benzoyl-L-arginine ethyl ester (1000 nmol). Mobile phase: $10 \mathrm{mmol} / \mathrm{l}$ sodium phosphate buffer (pH 6.8); flow rate: $1.5 \mathrm{ml} / \mathrm{min}$; detection: $254 \mathrm{~nm}$; column: immobilized trypsin column $(150 \times 4.6 \mathrm{~mm}$ i.d. $)$ connected with Cosmosil $5 \mathrm{C} 18$ $(30 \times 4.6 \mathrm{~mm}$ i.d. $)$; column temperature: $25^{\circ} \mathrm{C}$.

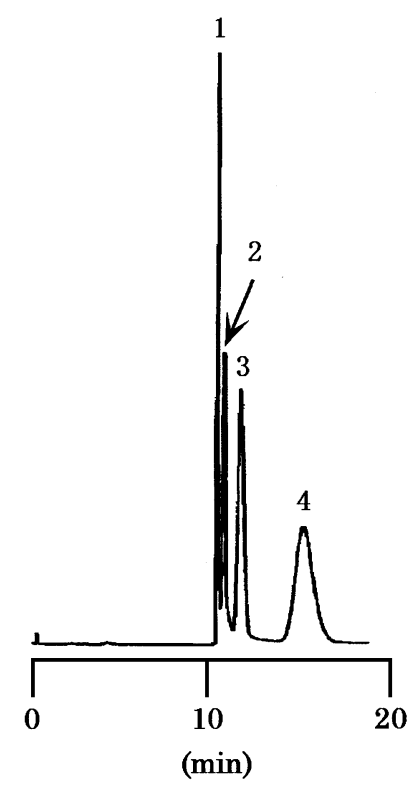

Fig. 4 Chromatograms of $N$-demethylation of $N, N$-dimethylaniline on immobilized Cyt-c column. Mobile phase: $10 \mathrm{mmol} / \mathrm{l}$ sodium phosphate buffer ( $\mathrm{pH} \mathrm{7}$ ); flow rate: $2 \mathrm{ml} / \mathrm{min}$; detection: $230 \mathrm{~nm}$; column: immobilized Cyt- $c$ column $(30 \times 4.6 \mathrm{~mm}$ i.d. $)$; column temperature: $30^{\circ} \mathrm{C}$. Peaks: 1 , hydrogen peroxide; 2 , aniline; $3, \mathrm{~N}$ methylaniline; $4, N, N$-dimethylaniline.

under the same analysis conditions. The results indicated that the phospholipid as a coating support would stabilize the immobilized enzyme, and its suitable conformation between the enzyme and phospholipid based on the lipid-protein interactions could produce the intrinsic activity of the enzymes. These finding suggested that the phospholipid column could be a useful support for immobilizing enzymes.

\section{Evaluation of the immobilized Cyt-c column}

Cytchrome- $c$ (Cyt- $c$ ) is one of the electron transport hemoproteins located on the biomembrane surface and usually does not catalyze the oxidation reaction. However, Cyt- $c$ is known to show $N$-demethylase activity on addition of an oxygenating agent. ${ }^{14,15}$ We prepared the immobilized Cyt- $c$ phospholipid column and studied the $N$-demethylase activity of 
(a)

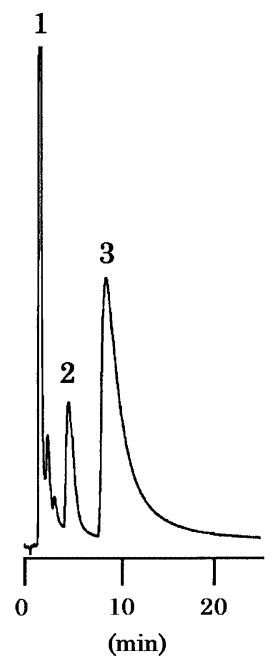

(b)

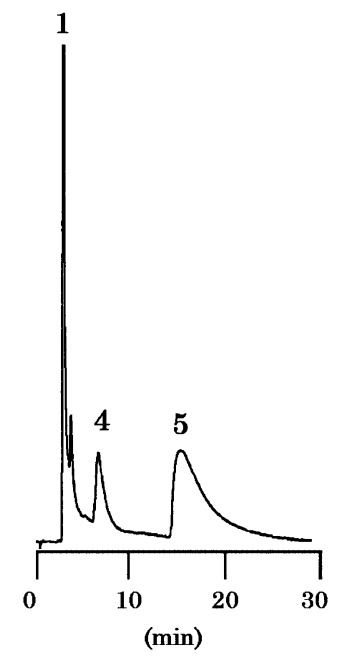

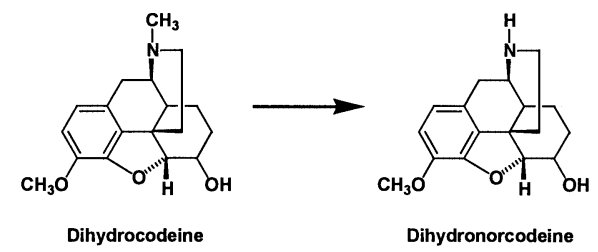

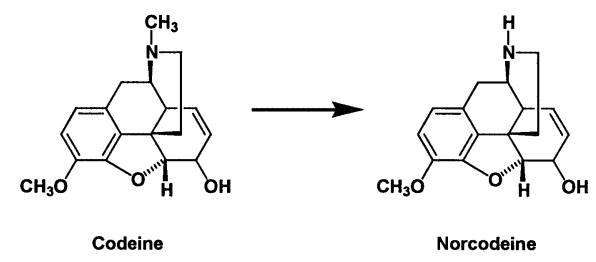

Fig. 5 Chromatograms of $N$-demethylation of dihydrocodeine (a) and codeine (b) on immobilized Cyt- $c$ column. Mobile phase: $10 \mathrm{mmol} / 1$ sodium phosphate buffer ( $\mathrm{pH} 7$ ); flow rate: $1 \mathrm{ml} / \mathrm{min}$; detection: $210 \mathrm{~nm}$; column: immobilized Cyt- $c$ column $(30 \times 4.6 \mathrm{~mm}$ i.d. $)$ connected with Develosil TMS-5 $(10 \times 4.6 \mathrm{~mm}$ i.d. $)$; column temperature: $30^{\circ} \mathrm{C}$. Peaks: 1 , hydrogen peroxide; 2, dihydronorcodeine; 3 , dihydrocodeine; 4 , norcodeine; 5 , codeine.

Table 2 Relationship between amount of hydrogen peroxide and amount of products on immobilized Cyt- $c$ column

\begin{tabular}{cccccc}
\hline $\begin{array}{c}\text { Amount of } \\
\text { hydrogen peroxide/ } \\
\text { nmol }\end{array}$ & \multicolumn{2}{c}{ Product/nmol } & $\begin{array}{c}\text { Unreacted } \\
\text { substrate } \\
\left(\mathrm{DMA}^{\mathrm{c}}, \mathrm{nmol}\right)\end{array}$ & $\begin{array}{c}\text { Recovery } \\
(\mathrm{nmol}(\%))\end{array}$ \\
\hline 100 & 1.8 & 0.3 & 2.1 & 8.6 & $10.7(107)$ \\
200 & 2.4 & 0.6 & 3.0 & 7.7 & $10.7(107)$ \\
500 & 3.2 & 1.4 & 4.6 & 5.2 & $9.8(98)$ \\
1000 & 2.8 & 2.2 & 5.0 & 2.7 & $7.7(77)$ \\
\hline
\end{tabular}

Injection amount of substrate was $10 \mathrm{nmol}$ of DMA.

a. $N$-Methylaniline.

b. Aniline.

c. $N, N$-Dimethlyaniline.

the column using hydrogen peroxide as the oxygenating agent. We tried various methods of adding the oxygenating agent during the separation. First, the solution of $N, N$-dimethylaniline (DMA) as substrate was injected onto the immobilized Cyt- $c$ column with a mobile phase of sodium phosphate buffer $(\mathrm{pH}$ 7.0) containing hydrogen peroxide solution. However, oxidation was not recognized in the column, as no $\mathrm{N}$ demethylation products were formed, the immobilized Cyt- $c$ would have been inactivated by the mobile phase containing hydrogen peroxide passing through the column. Next, we tried injecting the hydrogen peroxide solution onto the column after injection of the substrates. Oxidation products $N$-methylaniline (MA) and aniline (AN) were formed in $32 \%$ and $14 \%$ yields, respectively, after $10 \mathrm{nmol}$ of DMA was injected onto the column before injection of $500 \mathrm{nmol} / 10 \mu \mathrm{l}$ of hydrogen peroxide solution, as shown in Fig. 4. Both substrate and products were simultaneously separated on the column and detected after the $\mathrm{N}$-demethylation. The $\mathrm{N}$-demethylation was induced by successive injection of the oxygenating agent when hydrogen peroxide solution passed through the previously injected substrate band in the column. Table 2 shows the relationship between the injected amount of hydrogen peroxide solution, the total amount of products and the unreacted DMA when $10 \mathrm{nmol}$ of DMA was injected onto the column. The amount of products increased with an increase in the injected amount of hydrogen peroxide solution. Reaction yields were $32 \%$ for MA and 14\% for AN, respectively, when $500 \mathrm{nmol}$ of hydrogen peroxide solution was injected onto the column. The total yields of the products increased when $1000 \mathrm{nmol}$ of hydrogen peroxide solution was injected; however, the recovery rate decreased because the expected DMA was not eluted from the column.

We also have investigated the in-column oxidation of drugs using the Cyt-c immobilized column in a similar manner. Figure 5 shows the chromatograms when $500 \mathrm{nmol} / 10 \mu \mathrm{l}$ hydrogen peroxide solution was injected onto the column after injection of $1 \mu \mathrm{g}$ each of dihydrocodeine (DHC) and codeine (C) as the substrates. $N$-Demethylation products, dihydronorcodeine (DHNC) and norcodeine (NC), were formed in yields of approximately $10 \%$ each. Both substrate and products were simultaneously separated and detected, similar to the case of DMA. In this reaction system, $O$-demethylation products of the substrate, morphine and dihydromorphine were not formed under the oxidation conditions. $N$-Demethylation of DMA, MA, DHC, or C in this system was not affected by column temperature or by the flow rate of the mobile phase. For identification of the $N$-demethylation products, the peak fractions containing the $\mathrm{N}$-demethylation products eluted from the column were collected and the fraction solutions were determined by HPLC with photodiode-array detection. The uv spectra of MA, AN, DHNC, and NC of the fraction solutions were identical with those of the standards.

\section{Stability of immobilized enzyme column}

The hydrolytic activities of the trypsin immobilized column were stable for at least 20 injections of the substrates. The $N$ demethylase activities of the Cyt-c immobilized column were similarly stable for at least 20 injections of the substrates and hydrogen peroxide solution. 
Regeneration of immobilized enzyme column

Forty milliliters of $30 \%$ aqueous acetonitrile solution containing $0.1 \%$ trifluoroacetic acid solution were delivered through the enzyme columns, followed by washing with pure water in order to remove the inactivated enzymes. The enzyme was again immobilized on the phospholipid column with the same procedure as described earlier. In this manner of regeneration, the phospholipid was adsorbed again on the ODS phase and the enzyme activity was completely recovered. The results indicated that the immobilized enzyme columns could be easily regenerated without damaging the phospholipid column. Thus, the original phospholipid column could be repetitively used for enzyme immobilization.

\section{Conclusion}

Trypsin or Cyt- $c$ immobilized columns were readily prepared by recycling solutions containing trypsin or Cyt-c through the phospholipid column. Trypsin and Cyt- $c$ immobilized columns displayed hydrolysis and oxidation activities, respectively. The immobilized enzyme columns could be readily regenerated allowing repetitive use of the original phospholipid column. These immobilized enzyme phospholipid columns should be useful as enzyme reactors for HPLC.

\section{References}

1. N. Kiba, Y. Goto, and M. Furusawa, J. Chromatogr., 1993,
$620,9$.

2. K. Matsumoto, M. Takahashi, N. Takiyama, H. Misaki, N, Matsuo, S. Murano, and H. Yuki, Clin. Chim. Acta, 1993, $216,135$.

3. T. Fossati, M. Colombo, C. Castiglioni, and G. Abbiati, J. Chromatogr. B, 1994, 656, 59.

4. J.-F. Jen and M.-Y. Tsai, J. Chromatogr. B, 1994, 658, 87.

5. K. Hiramatsu, S. Kamei, M. Sugimoto, K. Kinoshita, K. Iwasaki, and M. Kawakita, J. Biochem., 1994, 115, 584.

6. S. Thelohan, $\mathrm{Ph}$. Jadaud, and I. W. Wainer, Chromatographia, 1989, 28, 551.

7. T. Alebic-Kolbah, G. Félix, and I. W. Wainer, Chromatographia, 1993, 35, 264.

8. W.-K. Chui and I. W. Wainer, Anal. Biochem., 1992, 201, 237.

9. C. Pidgeon and U. V. Venkataram, Anal. Biochem., 1989, $176,36$.

10. X.-M. Zhang and I. W. Wainer, Tetrahedron Lett., 1993, $34,4731$.

11. T. Alebic-Kolbah and I. W. Wainer, J. Chromatogr., 1993, 646, 289.

12. T. Alebic-Kolbah and I. W. Wainer, J. Chromatogr., 1993, 653, 122.

13. H. Kamimori and M. Konishi, Biomed. Chromatogr., in press.

14. I. Hamachi, A. Fujita, and T. Kunitake, J. Am. Chem. Soc., 1994, 116,8811

15. G. L. Kedderis, D. R. Koop, and P. F. Hollenberg, J. Biol. Chem., 1980, 255, 10174. 